5、病型では潰厦、次いで腫脹に効果が著しい。 唯、披裂間部の肉芽樣腫脹に対，しは殆ど効果を認 め得ない。

6、自覚症狀は局所の 変化に 先立つて速かに消 失する。

7、スによる喉結浩癒は全身狀態の 良否に 影響 される。然し、スの墦量によつて或る程度克服出 來る。

8、スによる浩癒には再発を認める事があるか
ら、使用量は十分でなければならない。

9、スの使用は、動脈注射法が効果最も顯著で ある。然し、之のみでは再発を來す事が多いから 引続き筋肉注射法を継続しなりればならない。

本研究には交部省科学研究費の補助を受けけ。追記し て謝意を表す。

一部症例の提供をいだ゙いけ兵庫療荃所小川博士に謝 意を表す。份、本諭交の要旨は第51回日本耳鼻咽喉科學 会総会に於て口演した。

\title{
咽喉頭結核に對するストレプトマイシン治効に關する 組織学的追求
}

\author{
京都大学耳鼻咽唉科敉室 \\ 廣 戶幾一郎 \\ 國立療养所春霞園 \\ 阪 東 和 一 郎
}

咽喉頭結核症のストレプトマイシン（以下スと 略称す）治療成績に就ては、別報の如くである。 ス治療 37 症例の內、12 例に対しては、治療前後 に病巢部を試驗切除して、スの治療效果を組織学 的に檢索した。てっではその結果に就て報告す る。

咽喉頭病巢部を一部切除する事は、病症の経過 に何等惡影響を及㤬さないのみならず、反つて治 療的効果を示す場合すらあるものである。前に後 藤・廣戸・值賀は乙の方法を用い㗋頭結核の病狀 推移を経時的組織学的に追及しているが、今回の ス沿療の成績は之己対比して観察した。結核屍に よるス治効の檢討は、我國に於ても二三報告があ るが、我ふの場合は 1) 臨床症例であるてと。

2) 同一症例略々同一部位のス洽療過程を経時的 に観察しているてと 3) 個体の抗病力尚盛故る時 期の組織所見の追及である点で病理解剖屍の場合
（主任 後藤㸚授）

野 崎 薩 夫

（園長 工藤博士）

とは異つた意義が存すると思う。

\section{檢索材料及び檢索方法}

1、京都大学耳鼻咽喉科呚室、春霞園潦養所に於てス 治潦え行える咽喉頭結核患者 12 例方対象こし け。

2、 、治療前、治療中、治療後に咽犊頭局所の病変最 も激烈なる部边選択的に切除して检查に供した。 第 2 回以後の切除は前回切除部位に成る可く近接 して然も病変盛なる部に行つた。

3、切除組織㸝は $10 \%$ ホルマリン水固定後 10 ミクロ ンのパラヒン切片さし、主るしてへマトキシリン・ エオシン染色、ヘマトキシリン・アニリン水フクシ ン染色を行つた。

\section{檢 索 成 績}

1、咽 頭 結 核

32才 男

(附図 1 及び 2 )

一般狀態良好。雨肺尖部陰影軽度。其の他眠野に変化 なし。咽頭後壁は下咽頭に至る廣大なる潰瘍めり、被苔 屯。披裂部に軽度浮腫ある他喉頭に異常なし。ス筋注 
2gr で潰瘍淸淨ミなり、30 gr で消失す。スの效果大であ る。

$9 \mathrm{gr}$ 目所見 $(9 / \mathrm{X})$ 咽頭潰痬㲽緣：潰瘍方形成せす。 粘膜上皮下は沉発性單球、及び類上皮細胞浸潤巢よりな る。一部に結核結節が累積するが、結節內部構造は柾で周 团の單球リンパ球浸潤が內部に迄波及している。菌(一)

$40 \mathrm{gr}$ 後所見 $(10 / \mathrm{X}$ 同上部位) : 粘膜上皮健存。結合 織線維增多が著明。血管拡張は著明でないか軽度の浮腫 え認める。粘膜上皮直下にラ巨細胞え有する結節え認め

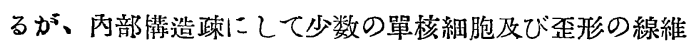
芽細胞の侵入え想め、一見して極めて鱓力性である。結 節周囲の細胞浸潤江極めて少い。結核菌（一）。

29才 男

一般狀態 極めて不良。粟粒肺結核で空洞 おり、軟口 蓋、咽頭後壁に廣範なる潰瘍わり。喉頭蓋、披裂部浮腫 狀腫脹。呢頭內腔側壁腫脹し被苔す。既にス15 gr使用後 入院す。

入院時所見（ス15 gr目、11/XI 口蓋垂）：粘膜上皮: 稍了肥厚。單球及び類上皮細胞の沉発性浸潤よりなる。

ス使用中、一時腫脹の減退せる軟口蓋、披裂部に再び 浮腫が篁强した。咽頭潰湯は15 grで消失している。咽頭 に於けるスの効果大。

$37 \mathrm{gr}$ 目所見 ( $16 / \mathrm{XII}$ 同上)：粘膜上皮肥厚。リンパ管 開大し、水腫著明。プラズマ細胞、リンパ球、單球、類 上皮細胞及び少数の多核白血球の散在性浸潤九認める。 処々に核破壞物質も認められ、結節の吸收像ではないか き思われる。

\section{2、喉 頭 結 核}

22才 女

一般狀龍良好。兩上肺野に滲出性空洞。咽頭後壁に小 豆大潰痬 3箇, 喏頭蓋、披裂部発赤浮腫狀腫脹。左喉頭 内㬵側壁に潰湯めり、被苔す。

又使用前所見 $(24 / \mathrm{V}$ 左仮声帶)：潰湯㤂形成す。潰 痬面表層に近く多核白血球の游出著明，潰瘍下組織は沉 発性單球及び類上皮細胞組織よりなる。一部に巨細胞を 認める。結核菌 III 一囵（600 倍拡大でガフキー表に準據 寸) 。

ス 1 回 $1 \mathrm{gr}$ 上甲狀腺動脈直接注射 (以下單に動注る略 称）約1週間隔3回施行。咽頭及び內腔側壁の潰痬消失。 浮腫減退す。

$3 \mathrm{gr}$ 動注後所見 ( $9 / \mathrm{VII}$ 同上)：薄い上皮形成さる。 互細胞れ含も結節の累積よりなる。結節周㲽の單球及び リンバ球浸潤は密実廣範である。一二の結節は中心部乾 酪化し多核白血球の殘䯓方認めるものもおる。單球リン パ球浸潤の中に少数の好酸球が混在する。結核菌 $(一)$ 。
2ケ月後咽頭に潰痬再発。ス筋泩 $10 \mathrm{gr}$ で消失す。更に 2 个月後啒頭蓋浮腫狀に腫脹しけシか、ス筋泩 $7 \mathrm{gr}$ で軽快 す。此の例は其の後不慮死え逐げけ。

剖檢時所見 (同上)：薄い上皮形成。血管拡張 充滿 し、浮腫な認める。單球リンパ球プラズマ細胞の沉発性 浸潤か認めるが、処々に類上皮細胞及びラ巨細胞の混在 ち認める部もある。

四男

一般狀態極めて不良，粟粒肺核核。喉頭蓋発赤腫脹乙 潰瘍あり。被苔す。

使用前所見 $(12 /$ 亗I 喉頭蓋)：潰痬形成。潰瘍面は多 核白血球單核球え含むフイブリン析出層に被わる。稍了 深部には小結核結節が累積し其の中心部は乾酪化してい る。結節周辺の單球リンパ球 浸潤は高度且つ廣範であ る。結核菌血。

又筋注10gr で潰演消失。発赤腫脹軽快寸。

$10 \mathrm{gr}$ 後所見 ( $3 / \mathrm{VI}$ 同上)：上皮肥厚。内部に岬狀に资 入している部もある。盈管リンパ管の拡張著明。一部に は浮腫か認める。沉発性單球及び類上皮紬胞組織よりな V、好酸球か含主少数の多核白血球が混在す。結核菌 (一)

$10 \mathrm{gr}$ 後所見（13/VI 同上）：上皮は薄。集合性小結核 結節よりなる。結節周辺の單球、リンパ球浸潤は密実で ある。結節內部は眯で、多くはラ巨細胞か含す。周囲の 單球、リンパ球浸潤は結節內部迄侵入している。結核菌 (一)。

更に2カ月後ス筋注 $10 \mathrm{gr}_{\text {。 }}$ 喉頭蓋は凹凸不本瘦痕樣。 スによる軽快例である。

$20 \mathrm{gr}$ 後所見 $(12 / \mathbb{X}$ 同上)：上皮健存，集合性小結核結 節よvなる。畧了 $13 / \mathrm{V}$ の組織像に似る。唯僅かに結合 織の算生方認めろ。結核菌（一）。

\section{回 男}

一般狀態極めて不良。粟粒結核。咽頭後壁及び口蓋扁 桃に小結核性潰瘍多数。喉頭蓋は凹凸不斥に赤発腫脹し 潰富あり。

ス使用前所見 $(2 /$ 䜣啒頭蓋)：粘膜上皮は薄。一部は 潰瘍形成，累々けるる類上皮細胞結節の集合よvなる。殆 ミ゙沉発性類上皮細胞組織ミ云つてもよい組織像で細胞浸 潤密実である。結核菌 YII

ス1日量 $0.5 \mathrm{gr}$ 宛 50 日間 (25gr) 筋注。咽搌頭は肉眼 的に殆ご正常そなる。即ち、臨床的全治例である。

$25 \mathrm{gr}$ 後所見 $(12 / \mathrm{X}$ 同上)：粘膜上皮肥厚。結合織線 維增多し、其の間に非定型的小結核結節九認める。一部 粘膜直下に類上皮細胞組織が殘存し、多核白血球の混在 方認めるが、好酸球の游出が多い。結核菌 (一)。

其の後 3 週目に結核性腦膜炎にて死亡す。 
剖檢所見 $(30 / \mathbb{X}$ 同上)：潰晹方認めす。結合織線維 增多す。血管リンパ管開大し浮腫著明。处々粘膜上皮下 に類上皮細胞性小結節、單球性細胞浸潤巢が結合織に包 埋されて散在する。又、プラズマ細胞リンパ球浸潤も散 在性に認める。

\section{6才男（附図ミ及び4）}

一般狀態極めて不良。雨上瞄野に空洞めり。混合型。 喉頭蓋発赤腫脹し、兩披裂部発赤、左仮声帶発赤腫脹、 潰瘍め叮。被苔す。

使用前所見 $(18 /$ 吕呢頭蓋)：粘膜上皮肥厚。亏互細 胞主含も結節散在す。周囲の單球りンパ球浸潤は顯䓔で あろ。結核菌 (一)。

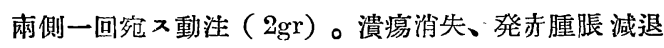
寸。

$2 \mathrm{gr}$ 動注淡所見 $(12 / \mathbb{X}$ 同上)：上皮肥厚。前所見に比 乙、結合織增多著明。結節は內部柾で、無力性。結核 菌 (-)。

其の後 2 月目に潰痘再現せるも、ス $10 \mathrm{gr}$ 筋注で消失す。

ス $10 \mathrm{gr}$ 筋注後所見 $(8 / \mathrm{XI}$ 同上)：上皮稍? 肥厚。結 合織增坐顯著。粘膜下に散在性に小数の類上皮細胞九含 毛單球りンパ球浸潤主認からのみ。

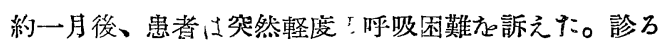
き犊頭蓋が著明に浮腫狀に腫脹している。又、再発では ないかる試切してみけが、組織所見は次の如く唯浮腫を 認めけたたけであつけ。

所見 $\left({ }^{10} / \mathrm{XII}\right.$ 同上)：上皮肥厚。血管リンパ管開大し 浮腫著明 粘膜上皮下に少数のプラズマ細胞、リンパ球 が散在性に浸潤ててている。結核結節は2 2個孤在す万が、 何れる結合織に囲まれ、結節內部に迄 線維芽細胞 侵入 す。周辺細胞浸潤殆ごなし。

\section{0于 男}

一般狀態稍了不良。左右上中眠野に洷出性陰影山り、 小空洞九有す。凂頭蓋、仮声帶発赤腫脹す。喉頭蓋の腫 脹洔に强度である。不筋注 $20 \mathrm{gr}$ で発赤腫脹軽減す。

ス $6 \mathrm{gr}$ 使用所見 $(2 / \mathrm{VI}$ 犊頭蓋)：上皮は薄。血管リン パ管拡張し、軽度の浮腫え認める。累ふけろ小結核結節 の集積よりなり、結節周囲浸潤に好酸球の混在か認め ろ。結核菌 (一)。

ス $17 \mathrm{gr}$ 使用目所見 $(13 / \mathrm{VI}$ 同上)：前所見に畧了同じ。 細胞浸潤密実。結核菌 (一)。

2 力月後、兩側一回宛入 $1.0 \mathrm{gr}$ 動注方行う。更に3カ月 後ス $20 \mathrm{gr}$ 筋泩。啒頭蓋及び 仮声帶の発赤腫脹極めて輕 快し、被裂閒部に輕度の肉芽樣腫脹な殘すのみである。

ス $32 \mathrm{gr}$ 使用後所見 $(12 / \mathbb{X}$ 同上) : 軽度の浮腫 あり。 この部には少数の類上皮細胞え混じ、プラズマ細胞及び
單球が散在性に浸潤す。少しく深部に前所見に類似する 小結核結節果倩巢おり。細胞浸潤密実。結核菌 (一)。

\section{4 女 女}

一般狀態良好。肺は增殖型。喉頭蓋発赤腫脹す。左仮 声帶発赤し潰湯あり。被苔す。

又使用前所見 $(17 /$ 四啹頭蓋 $)$ : 血管㧨張し、浮腫山 り。粘膜上皮下には、單球及び類上皮細胞の散在性浸潤 あり。結核菌 (一)。

ス $10 \mathrm{gr}$ 筋注、 $1 \mathrm{gr}$ 動注により潰湯消夫。発赤腫脹も軽 減寸。

又使用後所見 $(12 / \mathbb{X}$ 同上)：浮腫 著明。粘膜上皮下 には少数のプラズマ細胞及びリンパ球浸潤を認的万。前 所見に比し病変極めて軽度。

\section{1才男}

一般狀態極的て不良。雨上肺野渗出型。左に空洞 お v)。唉頭蓋発赤腫脹著明、潰瘍めり。兩側仮声帶及び声 帶腫脹す。

又使用前所見 $(16 / \mathrm{VI}$ 唉頭蓋)：上皮は薄。血管リン パ管拡張す。小結核結節 であ万。結核菌 (一)。

又動注 $2 \mathrm{gr}$ 、蝣注 $1 \mathrm{ugr}$ 个潰痬 消失し、発赤腫脹軽快 寸。

ス使用後所見 $(8 / \mathrm{XI}$ 同上)：小結核結節が集合し、多 くはラ巨細胞え含も。結節問の結合織線維の習生著明。 結節周囲の細胞浸潤極めて少し。

\section{4才 男}

一般狀態稍了不良, 兩肺空洞おり。混合型。㘈頭蓋発 赤腫脹菨明。潰痬あり。

又使用前所見 $(13 / \mathrm{VI}$ 喉頭蓋 $):$ 粘膜上皮肥厚。血管 リンパ管拡張し軽度の浮腫か認む。類上皮細胞結節集合 し、周辺に出血方認め万。結核菌 (一)。

ス 動注 $2.0 \mathrm{gr}$ て潰瘍消失。発赤腫脹減退寸。

又使用後所見 $(10 /$ VIII 同上)：粘膜上皮肥厚。結節内 及び周囲の細胞浸閵密実。結核菌 (一)。

又使用後所見 $(12 / \mathbb{X}$ 同上)：上皮肥厚。結合 織成分 增多。結合織に团まれて小結核結節か散見する。結節周 囲の細胞浸潤は極めて少い。

\section{8才 男}

一般狀態稍 、不良。左上肺野硬化性空洞おり。右肺混 合型。喉頭蓋発赤腫脹著明。兩仮声帶発赤腫脹。披裂間 部肉芽樣腫脹。

ス使用前所見 $(18 /$ IIII啹頭蓋)：血管リンパ管 拡張し 浮腫著明。処々粘膜上皮下に單球性浸潤巢あり。結核菌 (-)。

ス動注 $2 \mathrm{gr}$ により、発赤腫脹軽減す。 
ス使用後所見 ( $12 / \mathbb{X}$ 同上)：上皮肥厚。血管リンパ 管拡張し、浮腫劣著明。処々に出血す。粘膜下処々に單 球結節おり。結核菌 (一)。

\section{5才 男}

一般狀態良好。右肺增殖型。喉頭は披裂閒部肉芽㨾に

\section{增殖す。}

ス使用前 所見 $(17 / \mathrm{X}$ 披裂間部)：一部潰痬化し、伶 膜樣フィブリン析出著明。又一部には上皮肥厚し、内部 に岬狀に突入せろ部もおろ。單球リンパ球浸潤が著明で あろ。処々にラ巨細胞方含も結核結節の殘骸か認める。 結核菌 (一)。

ス10gr筋注。肉眼的にあまり変化はないが、試驗切除 の爲腫脹は小をなり自覚症軽快す。

使用後所見 ( $8 / \mathrm{XI}$ 同上)：上皮肥厚。結合織增多 寸。定型的結節なく、單球リンパ球浸潤を散在性に認め るに過ぎ。

ス使用後 所見（ $22 / \mathrm{XII}$ 同上）：上皮は薄。血管リンパ 管拡張し、浮腫著明。処々出血巢 $v$ v。粘膜下に散在性 にプラズマ細胞及びリンパ球浸潤方認める。

\section{4才 男}

喉頭蓋及び兩側真仮声帶の発赤腫脹おり。ス $80 \mathrm{gr}$ 使用 で腫脹はそれイシが、喉頭は誐痕樣に狭窄し、氣管切開及 び啹頭截開術により軽快した。声帶瘾著部所見は結合織 增多著明て、硝子樣㓔痕化え示している。結核性病恋は 何处にも認められない。

\section{總 括 涉に考按}

以上症例に於けるス使用法及び使用量は区くで あり、基準量 $40 \mathrm{gr}$ より遙か、少量使用の場合も あるが、何れも多少之も好轉の傾向か認められ る。

ス使用による組織像の変遷を追及すると、

1、上皮形成が速かである。從來の成績によれ ば、咽喉頭結核に於ける粘膜上皮の再生能力は余 程末期に至るまで盛であり、治癒に赴く場合は先 す上皮再生を認めるものである。スの場合は之が 極めて速かであり、潰廈に著效ありと云われる所 以でもある。

2、組織內結核菌が 急速に消失する。乙の所見 は特に顯著であり、当然結核菌を証明出來ると考 えられる組織像に於ても証明しない。（例之、安 岡 ${ }^{9} / \mathrm{IX}$ 、木部 $3 / \mathrm{VI}$ 。）之は從來の沿療法の場合之 は全く異る所であり、我々の檢素例中スを使用せ る場合は一例も結核菌を証明していない。動物実
驗によれば、乾酷巢以外の結核菌はアレルギー狀 態の如何を問わ和スに上り速かに消失する。元來 喉頭結核病巢には乾酷巢は稀であり、菌の存在は 類上皮細胞組織に最も多的ら、スの影響を受け 易いものであろら。

3、結節辺緣の單球リンパ球浸潤が 先 和減少す る。動物実驗に於ても認める所見であり、スによ る結節変化の最初の所見である。

4、次いで結節は無力性となり、內部構造は踈と なり、結合織により包埋される。或虹周囲から 單球リンパ球、又は線維芽細胞が結節內儿侵入す る。赤崎氏等は病理解剖屍の所見から、スによる 沿癒の場合には先和病巢に著しい小円形細胞浸潤 を來すと述べているが、我々の所見では、殊て喔 頭にあっては、反つて先結節周辺の小円形細胞 浸潤が減少する。結節が种化し、單球リンパ球が 結節內部一侵入し、結節が分断吸收される頃にな つて始めてリンパ球、プラズマ細胞、單球の散在 性浸潤を認めるものである。（例之、鉔冶 ${ }^{30} / \mathbb{I X} 、$ 福田 ${ }^{16} / \mathrm{X}$ 㧫。)

.5、結合織線維の增多は、多少共必打認められ る。

6、スにより結核病巢が沿瘾するには、2つ方向 がある。即ち、結合織の增多が著明で、硝子樣に 全く旅痕化してしまう場合（櫻場）と、結合織增 生が顯著でなく、結節が吸收消失する場合(鉔冶、 小林）とである。然し、スによる沿瘾過程に於て 結合織線維の增多は認めても、最終治瘾像に於て 瘢痕を認める樣な場合は少的。般痕形成に関して は、岩崎氏は、病変が稍々陳旧となり、結合織增 殖が盛となつを時期飞スを使 らと、六㞧々之を助長 する䉆であろ5之考充、赤崎氏等は、腸結核では 古くなつた病巢では結合織つ增殖が强く、新しい 場合仕殆ど認められないと云つている。我ふは動 物実驗では、内分泌変調とヒペルェルギー性炎と の複合によるものではなかららかと推測したが、 或いは病変の强弱、新古とも関係があるものかも しれない。

從來喉頭結核の臨床的浩療例之称されるもの でも、組織学的飞檢查すると隨分永く結節を証明 出來るものである。我々は之を、結核生菌は消隇 しても菌体フラクションが永く組織內に停滯する 
爲の組織反應であると考えて來た。然し、ス使用 の治癒例に於ては、結節の消失が速かである。之 が同じく治癒と云い乍ら、スによるるのと然らざ るものとの相異点である。從來の沿癒例と称した ものの組織像は、矢張り結核菌の存在、例えば非 抗酸性形態（植田）によるものではなかららか。 スによる治癒後は再発が少いと云われる事も、從 來の治癒例が完全治癒でをかつを事を意味してい はしまいか。再檢討を要する問題であろう。

7、ス使用中、叉は使用直後に、病巢部に浮腫 を認める事がある。（例之、小林、福田）之は炎 性のものではなく、スによる血管壁透過性の增大 に基くもの之考える。

\section{結論}

咽喉頭結核のス治療過程を病理組織学的に追及 した。其の結果は、

1、上皮形成が速かである。

2、組織內結核菌が急速に消减する。

3、結節周辺の 小円形細胞浸潤が、先ず渻失す る。

4、結笻は疎化し、單球リンパ球の侵入によつ て分断吸收される。

5、結合織の增多は多少共必認められる。

6、スによる結核病巢の治療には、瘢痕化と吸 收沙失とあり、後者による場合が多い。

7、ス治療中には、病巢部浮腫を招來する場合 がある。

恩師後藤呚授の御指導御饺閵九深謝す。又、取材の便 宜が與えられた:春霞園院長工藤博士站に兵庫療養所ふ長 小川博士に深謝す。

本研究には文部省科学研究費及びストレプトマイシン 科学研究費の援助れ受けた。佾本論文の一部は第51回日 本耳鼻咽喉科学会総会に於て口演しホ。

\section{主 要 文 献}

1、後藤、廣戶、値賀

2、赤崎

3、相磯、島本

4. 大藤
日本臨床結核 7卷 4 号 臨床 3 卷 3 号 154 ストレプトマイシンを結核 療法

臨床 2卷 581
第一圖：咽頭結核（安岡例） $29 \mathrm{gr}$ 目所見。 潰瘍辺緗部。密実なる 單球類上皮細胞浸潤巢よりな り、処ふに結核結節が点在するが、結節内部構造は蹯 て、單球リンパ球浸潤が內部に迄及人ている。一部結節 には、ラ巨細胞え認める。結核菌は既に認めない。

第二圖：同上、ス $40 \mathrm{gr}$ 後所見

潰場は兓に認めない。結合織線維增多が著明。軽度の 浮腫わ認めるが、血管拡張は著明てない。ラ巨細胞え含 主結核結節が少数殘存するが、內部荊造は柾で、少数の 單核細胞及び歪形の線維芽細胞が侵入して居り、一見し て極めて哭力性である。結節周辺の細胞浸潤し少く、勿 論結核菌は認められない。

第三圖：喉頭結核 (小林例) 又使用前 $(18 / \mathrm{IIII})$

喉頭蓋。発掰腫脹す。粘膜上皮は健存してい゙る。ラ巨 細胞か含む結核結節が散在し、周困の單球リンパ球浸潤 は著明である。結核菌は認めない。

第四圖：同上，ス $2 \mathrm{gr}$ 動注、10gr筋注後 $(10 / \mathrm{XII})$ ス治療終了約 1 力月後に喉頭蓋浮腫狀に腫脹す。上皮 は健存。血管リンパ管開大し浮腫著明。上皮下に少数の 形質細胞、リン八球が散在性に浸潤している。結榜結節 は標本中僅かに2箇認めるに過きれが、夫も結合織に团 まれ、結節內部迄線維芽細胞侵入儿、周团の細胞浸潤方 認めない。結核菌 (一)。

第五圖：啹頭結核（櫻場）>80 gr筋注後所見。 眞仮声帶部の瘕痕性治痖像。

第六圖 ：動物実験。感作家兔に於㳡万 菌液注射 42 日目、 2.44 日間使用所見。

結合織線維の增生極めて顯著であろ。処々に類上皮細 胞そ單球の小浸潤巢はあろが、細胞密度極めて疎，第五 因瘕痕組織に酷似す。

第七圖 ： 動物実験。無感作家鬼に於け万菌液注射 21日目使用せす。

乾酪化結節方形成し、周辺の細胞浸潤も大。結核菌は 乾酪燷死巢丙次勿論、類上皮細胞層にも認める。

第八圖 ： 動物実験，無感作家兔に於ける 菌液注射 21 日目、ス23日間使用所見。

大小種々の類上皮細胞單球浸潤病巢が連接して居り、 其の間に多核白血球、リンパ球及び單球が散在性に浸潤 している。病巢部細胞密度は眯で病㮂が個々に分割吸收 される過程え示している。結核菌江認めない。対照であ る第七図そ比へるこ著しい差である。 


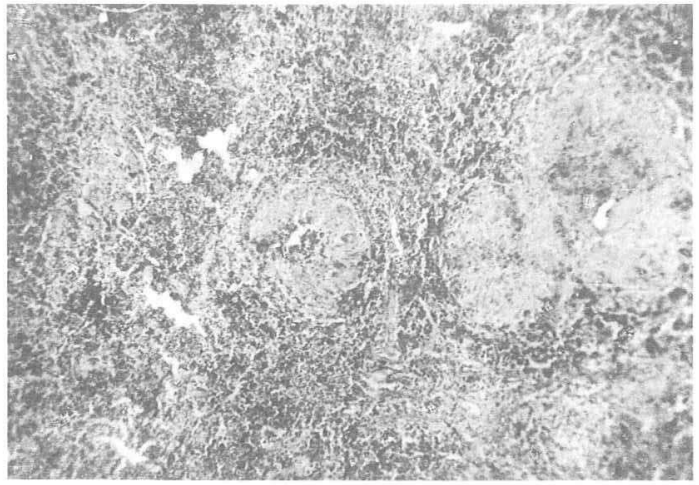
第1圖.

例。 又9瓦后（咽頭結核）
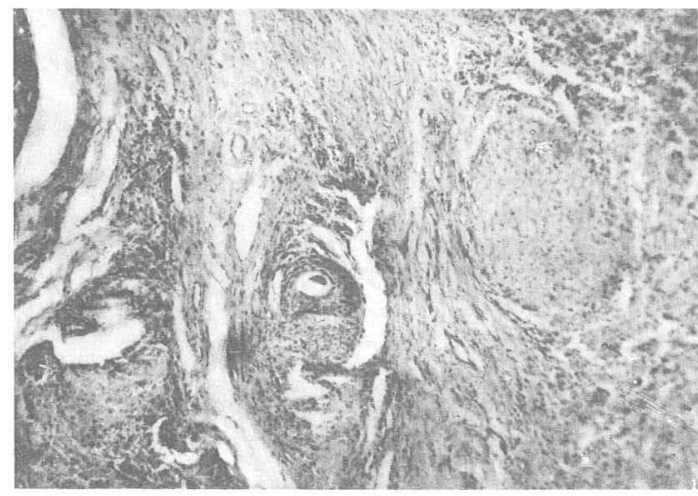

第2圆。

例. 又40瓦后（吠頭結核）

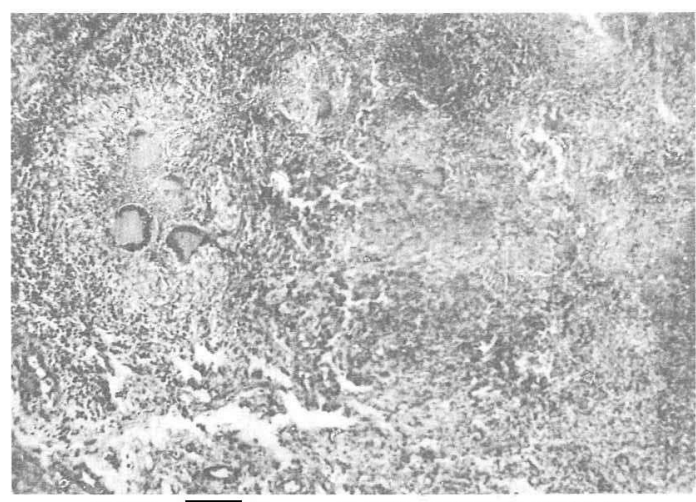
第3 圖.

$$
\text { 例。 ス使用前 (喉頭結核) } 18 / \text { III }
$$

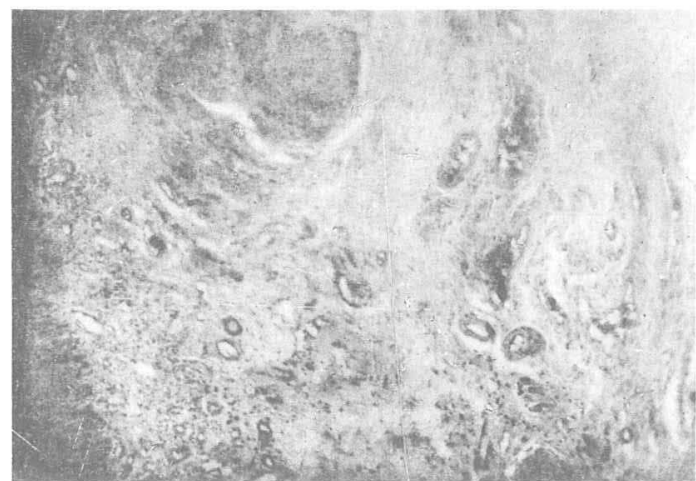

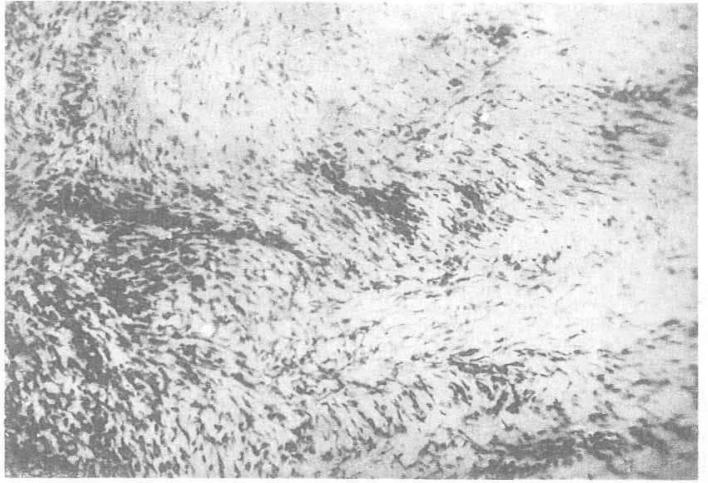

第5圖。
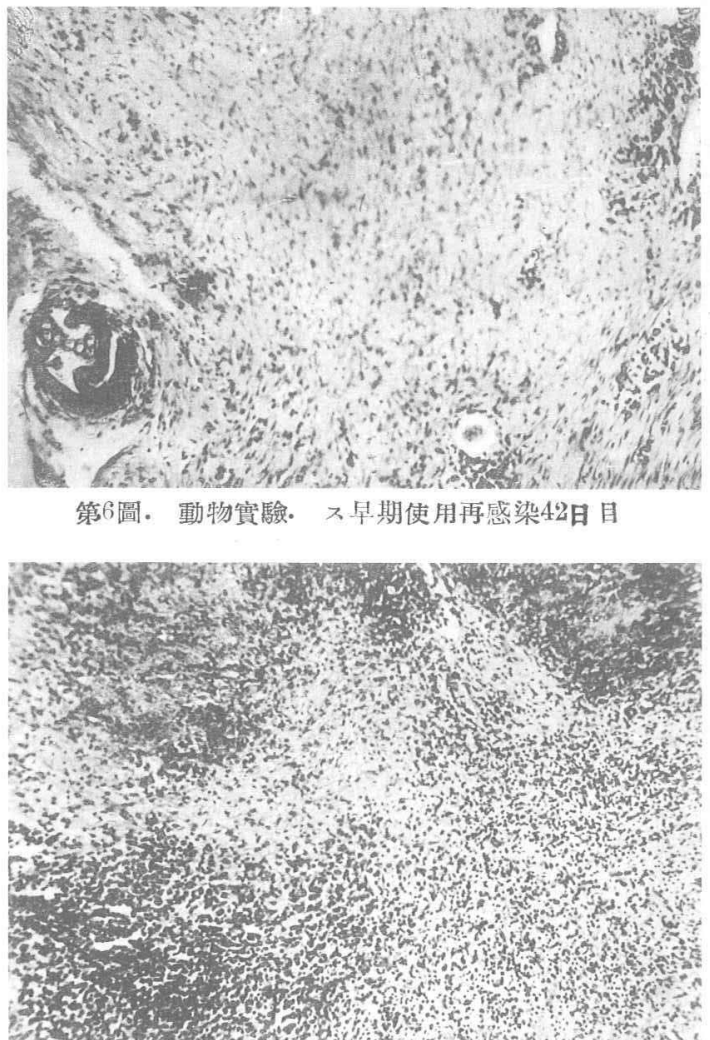

第7圖. 動物實㱆. 初感染21日目（對照）

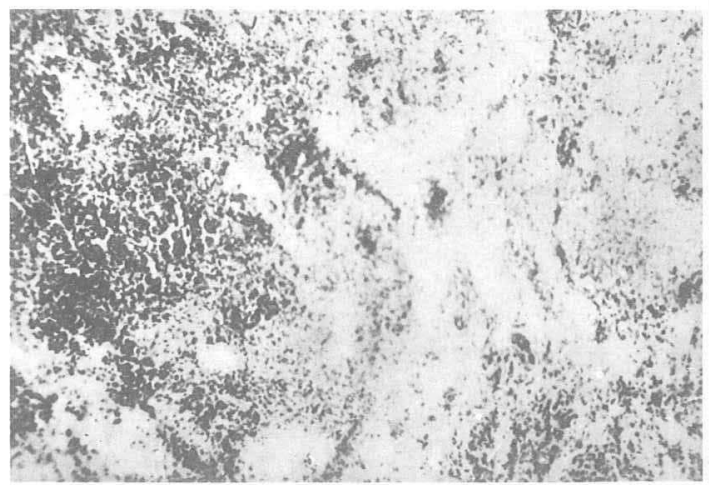

第8圖. 動物實驗. 万早期使用初感染21日目 